\title{
PORQUE ESPECIAL?
}

Manoel Aguiar ${ }^{1}$

\section{WHY IS IT SPECIAL?}

Resumo: "Amores Especiais", por quê? Será que a diferença de forma, cor, opção sexual e do fato de ser "deficiente", realidades e verdades do existir EXPRESSAS NA DIVERSIDADE E MODO SINGULAR DE SER E DO CORPO, impõe um modo ESPECIAL DO AMAR E SER AMANTE? Será que a relação de agir e interagir determina, de forma autoritária, o que é ESPECIAL, por conseqüência distanciando o viver e conviver do naturalmente natural? Então, ESPECIAL por quê?

Palavras-chave: Inclusão; sexualidade; desenvolvimento inclusivo.

Abstract: "Special Love", but why? Does a different shape, color, sexuality or just the fact of being "disabled", realities and truths of life, EXPRESS THROUGH DIVERSITY AND THROUGH A SINGULAR WAY OF BEING OR OF THE BODY, do these things impose a SPECIAL WAY OF LOVING OR OF BEING A LOVER?

Do the actions or interactions define, in an authoritarian way, what is special, and consequently tears apart the living from the naturally natural? And so, SPECIAL, why?

Keywords: Inclusion; sexuality; inclusive development.

Chegou o convite: Participar do XI Congresso Brasileiro de Sexualidade Humana-AMOR E SEXO NA CONTEMPORANEIDADE para, como um dos 'conferencistas' da Mesa Redonda Amores Especiais, proferir fala sobre $O$ amor entre os que não vêem com os olhos.

1 Chesf - Comitê de Responsabilidade Social. e-mail: maguiar@chesf.gov.br 
Fiquei muito honrado pelo convite e pela oportunidade ímpar de indagarmos: Mas, por que especial?

- E vêem como e por onde???

E aí, fiquei grilado. Muito encasquetado!

- Diferente entre os cegos???

- Será que sou eu mesmo quem deva contar esta 'excepcionalidade ESPECIAL'?

- Mas, quem disse que eu sou ESPECIALISTA ESPECIAL???

- E será mesmo ESPECIAL? Dizem que sim, e está em discussão no Congresso Brasileiro de Sexualidade Humana.

Pode ser diferente e, em sendo, o que acontecerá?

Dias à frente, convite para escrevê-lo 'especial', 'excepcional'. Em até vinte laudas, para a Revista Brasileira de Sexualidade Humana.

E se escreve, ou se vive e faz amor?

E o Kama Sutra falou como e o quê do especial e para os ESPECIAIS?

E Cupido, via ou não via?

Danou-se! É verdade. Não atirei a flecha em ninguém...

Vote! E o meu primeiro amor? Agora sei por que nem notou... Não era cega. Como, então, fazer ou viver o Amor com quem não vê?

Mas o amor não é cego?

E o que fazemos é diferente?

Será?

Ora, tem de ser às claras.

E "No escurinho do cinema”... (CARVALHO; LEE, 1982). É melhor? E por que apagam as luzes? E os que o fazem e curtem no escuro? Nas TREVAS? Eita! Pecado. Danou-se! O que fiz??? E as penitências ganhas no confessionário? $\mathrm{E}$ os pimpolhos, filhos do escuro, fazem ou farão diferente?

Virgem Maria!!! O que está acontecendo? Ora, curti? Fiquei? Amei??? Que fiz? E meus amores não foram nem são cegos! Ou foram cegos de amar?

Ah! Solução: um curso especial. No mínimo um mestrado. Ou PHD do Amor ESPECIAL. 


\section{E a TESE?}

'O especial e o especialista no e do amor inclusivo' ou 'as causas teratológicas e o interrelacionamento sexo-sentimental dos especiais para a construção de sua inclusão social'

Mas e a discussão, constatação e valorização do politicamente correto? Da segregação? Da discriminação? Da diversidade? Da diferença? Da singularidade? Da inclusão?

$\mathrm{E}$ as políticas e ações afirmativas para inclusão social do segmento?

Despiroquei: Ta grilado amor? Pai, qual é? Velho, te liga!

Oxente! O que é? O que será?...

Aí, me socorri dos poetas. Do amor, paixões e tesão dizem em poemas, prosas, músicas. Mas vivem e convivem suas intensas e incomensuráveis fantasias: a verdade e rolos e rolar do amar e do desejar. Inventam, reinventam. Mas não os conheço discriminando nem segregando o amor. Desejam-no único. Exclusivo. Eterno. Cúmplice do fogo, da chama flamejante. Paixão. Especial e exclusivo - diferente. Vida. À flor da pele.

“Infinito enquanto dure”... (MORAES, 1960, p. 96).

Sem rótulos. Sem preconceitos ou conceitos restritivos ou impositivos. Vivido, convivido no todo ou nos pedaços dos meandros e imensurável universo da dimensão do corpo, do desejo e do platônico.

Só. E tão só o amar e o amor.

E o meu e nosso amor?

“[...] Tem um jeito manso que é só seu

E que me deixa louco

Quando me beija a boca

A minha pele toda fica arrepiada

E me beija com calma e fundo

Até minh'alma se sentir beijada, ai” (BUARQUE, 1977-1978)

E o meu e nosso amor?

“[...] Tem um jeito manso que é só seu

Que rouba os meus sentidos

Viola os meus ouvidos

Com tantos segredos lindos e indecentes

Depois brinca comigo

Ri do meu umbigo

E me crava os dentes, ai” (id. Ibid., 1977-1978) 
O meu e nosso corpo é testemunha do bem que me faz.

Sem excepcionalidade. Sem indagações ou teorizações. Só. E tão só o amar e o amor.

Longe do ESPECIAL,

[...] especialista competente, isto é, daquele supostamente portador de um saber que os demais não possuem e que lhe dá o direito e o poder de mandar, comandar, impor suas idéias e valores e dirigir as consciências e açóes dos demais. (...) o especialista tem um poder de intimidação social porque aparece como aquele que possui o conhecimento verdadeiro, enquanto os demais são ignorantes e incompetentes. (CHAUÍ, 2007)

Muito obrigado por tão própria, simples e verdadeira constatação Professora Marilena Chauí.

Quase e no caso ESPECIAL, distantes do concreto. Do palpável. Do naturalmente NATURAL.

Não, não vamos por aí.

Ouçamos os que expressam naturalmente, o natural existir, sentir, SER.

"[...] Vem por aqui" — dizem-me alguns com os olhos doces

Estendendo-me os braços, e seguros

De que seria bom que eu os ouvisse

Quando me dizem: "vem por aqui!"

Eu olho-os com olhos lassos,

(Há, nos olhos meus, ironias e cansaços)

E cruzo os braços,

E nunca vou por ali...

(...)

Ah, que ninguém me dê piedosas intenções,

Ninguém me peça definiçōes!

Ninguém me diga: "vem por aqui”! (RÉGIO, “Cântico Negro”, 1925, p.59)

Logo, nos previnamos. Vigiemos e oremos. Guardemos com as bênçãos de Cupido e Vênus os seus ensinamentos e fluidos.

Longe disso tudo.

Sempre persistindo renitentemente crendo e perto do NATURAL. Perto do coração. Da cama que o acaso permite ou cria. Cúmplices unicamente do prazer e do se ter. Do envolver envolvendo-se. Do curtir-se. Do ficar. Do irresponsavelmente responsáveis pelo amar. AMANTES. Sem querer ou ser ESPECIAL. 
E de novo, me valho dos poetas:

[...] O que será que me dá

Que me bole por dentro, será que me dá

Que brota à flor da pele, será que me dá

E que me sobe às faces e me faz corar

E que me salta aos olhos a me atraiçoar

E que me aperta o peito e me faz confessar

$\mathrm{O}$ que não tem mais jeito de dissimular

E que nem é direito ninguém recusar

E que me faz mendigo, me faz suplicar

O que não tem medida, nem nunca terá

O que não tem remédio, nem nunca terá

O que não tem receita (BUARQUE, 1976)

Especial por quê??? Do plural porque único. Do diferente, mas não indiferente. Do singular, mas nunca ESPECIAL.

Amante do amor. Porque "Faz parte do meu show" (CAZUZA; LADEIRA, 1988).

E só.

\section{Referências bibliográficas}

BUARQUE, C. O meu amor. 1977-1978. Disponível em: <http://chico buarque.uol.com.br/letras/omeuamor_77.htm>. Acesso em: 28 jul 2007, $20 \mathrm{~h} 20 \mathrm{~min}$.

BUARQUE, C. O que será (À flor da pele). 1976. Disponível em:<http:// chicobuarque.uol.com.br/letras/flordate_76.htm>. Acesso em: 28 jul, $20 \mathrm{~h} 45 \mathrm{~min}$.

CARVALHO, R.; LEE, R. Flagra, 1982. Disponível em: <http://www.ritalee. com.br/estudio/letras1.asp?numero=125>. Acesso em: 28 jul 2007, $20 \mathrm{~h} 15 \mathrm{~min}$.

CAZUZA; LADEIRA, R. Faz parte do meu show. 1988. Disponível em: <http://www.cazuza.com.br/sec_discogra_view.php?language= pt_BR\&id=7>. Acesso em: 29 jul 2007, $21 \mathrm{~h} 15 \mathrm{~min}$.

CHAUÍ, M. A invenção da crise. Conversa Afiada, 30 jul 2007. Disponível em <http:/conversa-afiada.ig.com.br/materias/ 446501-447000/ 446655/446655_1.html>. Acesso em: 31/07/2007, 20h48 min.

MORAES, V. Antologia Poética. Rio de Janeiro: Editora do Autor, 1960, p. 96. RÉGIO, J. Poemas de Deus e do Diabo. (9a ed.) Porto: Brasília Editora, 1978, p. 59.

RÉGIO, J. (1925). Poemas de Deus e do Diabo. 9a ed. Porto: Brasília Editora, 1978, p. 59. 